\title{
Disrupting civility: amateur intellectuals, international lawyers and TWAIL as praxis
}

John Reynolds

To cite this article: John Reynolds (2016) Disrupting civility: amateur intellectuals, international lawyers and TWAIL as praxis, Third World Quarterly, 37:11, 2098-2118, DOI: 10.1080/01436597.2016.1197038

To link to this article: https://doi.org/10.1080/01436597.2016.1197038

册 Published online: 22 Sep 2016.

Submit your article to this journal

Џlll Article views: 457

View Crossmark data ¿ 


\title{
Disrupting civility: amateur intellectuals, international lawyers and TWAIL as praxis
}

\author{
John Reynolds \\ Department of Law, National University of Ireland, Maynooth, Ireland
}

\begin{abstract}
This paper is a reflection on the role of intellectuals in engaging with Palestinian solidarity movements and liberation discourses, and on the place of international lawyers specifically within that context. The paper considers 'the question of Palestine' as a rigorous test for intellectuals in the Global North today, and examines particular debates over free speech, civility and balance that unfolded in the wake of Israel's 2014 war on Gaza. It considers the interventions of international lawyers in these debates with reference to Edward Said's 'amateur' and 'professional' intellectuals, and explores ways in which anti-colonial international lawyers (as amateur intellectuals) can transcend prevailing professional orthodoxies to deploy language, arguments or tactics that rupture liberal legal processes and narratives on Palestine.
\end{abstract}

\section{ARTICLE HISTORY}

Received 11 February 2016

Accepted 31 May 2016

\section{KEYWORDS}

Palestine

Israel

civility

academic freedom

international law

praxis

TWAIL

colonialism

Edward Said

Steven Salaita

\section{Introduction}

It is a spirit in opposition, rather than in accommodation, that grips me because the romance, the interest, the challenge of intellectual life is to be found in dissent against the status quo at a time when the struggle on behalf of underrepresented and disadvantaged groups seems so unfairly weighted against them. (Edward Said) ${ }^{1}$

The @IDFSpokesperson is a lying motherfucker. (Stephen Salaita) ${ }^{2}$

This paper is a reflection on the role of intellectuals in engaging with Palestinian solidarity movements and liberation discourses, and on the place of international lawyers specifically within that context. My point of departure is Edward Said's Representations of the Intellectual, and the particular distinction Said draws between professional and amateur intellectuals (his twist on Gramsci's traditional and organic intellectuals or, from a more explicitly Third World perspective, on Fanon's colonial and native intellectuals). The paper considers 'the question of Palestine' as a rigorous test for intellectuals in the Global North today, and examines debates over free speech, political expression, academic freedom, civility and balance. It does so in the context of two particular 'affairs' that unfolded in the wake of Israel's 2014 war on Gaza, and that are indicative of broader restrictions on the intellectual space to critique such colonial violence. I present these examples as the Salaita affair (regarding Steven 
Salaita's loss of a tenured appointment at the University of Illinois over positions he expressed publicly during the Israeli bombardment), and the Schabas affair (regarding the campaign against William Schabas serving as chair of the UN Commission of Inquiry on the Gaza war).

The next section begins by elaborating Said's framing of the amateur intellectual in relation to contemporary debates on Palestine. The following two sections then use the Salaita and Schabas affairs to deconstruct the figure of the professional, conformist intellectual. The prevailing conventionalism ensured that mainstream international lawyers (as professional intellectuals) for the most part maintained conservative positions during these affairs and deferred to the presumed legitimacy of Israel's use of force. I interrogate and contest the paradigms of civility and balance that are imposed in this context. The fifth section moves to rehabilitate the partisan, subversive intellectual as a counterpoint. In doing so, I seek to build on Said's conception of the amateur intellectual by instilling a particular sense of partisanship that draws on Walter Rodney's notion of the 'guerrilla intellectual'. Following on from this, the sixth section begins to think normatively and prescriptively against prevailing professional orthodoxies, considering international law as a space of social movements as well as of elite institutions. I explore some of the ways in which anti-colonial international lawyers (as amateur intellectuals) can deploy language, arguments or tactics that subvert or rupture liberal legal processes and narratives on Palestine, and that may allow us to think about Third World Approaches to International Law (TWAIL) as praxis.

\section{Amateur intellectuals}

Given that the badge of professionalism is something that most lawyers will wear with pride, it must be emphasised at the outset that Said uses the term pejoratively, to unveil the depoliticised expert figure whose professional intellectualism is self-serving and deferential to established, and establishment, structures. For Said himself, by contrast, it is a spirit of opposition rather than accommodation that grips him. While his homage to the'romance' of intellectual life may connote a somewhat idealised self-representation of a critic who nonetheless had his own dalliance with the PLO hierarchy, his emphasis on dissent - against a status quo that is so unfairly weighted against subjugated groups - resonates today as sharply as ever in the Palestinian context. Israeli domination and segregation throughout historic Palestine continue to become both socially and legally more entrenched by the day, the colonisation of the West Bank carries on apace and the bombardments of Gaza become more brutal and ruthless in their mechanised violence. And while this hot violence of Israel's periodic wars on Gaza dominates our news feeds at sporadic intervals, the slow, cold violence of the state's legal armoury serves to entrench other particular forms of control in Israel and East Jerusalem. ${ }^{3}$

Where Said characterises the Dreyfus affair and the first world war as 'rigorous tests for intellectuals' in the early 20 century, ${ }_{1}^{4}$ the nature of Zionism and the situation in Palestine presents a comparably rigorous test for intellectuals in the early twenty-first century. It is by no means the only such test presented from that region of the world, but it remains arguably more significant than ever. The positions that we in the Global North take or fail to take on Israel/Palestine define our politics in relation to state power, to imperialism, to resistance, to the international donor industry. For Richard Falk, Palestine stands among the three pre-eminent issues for progressive emancipatory politics today. He places'support for the Palestinian Solidarity Movement, including its BDS campaign as... a creative form of resistance to oppressive circumstances' at the centre of the agenda, alongside the struggle against unjust and 
unsustainable forms of globalised neoliberalism, and the need to urgently address the ecological and existential threats of climate change. ${ }^{5}$ How we situate ourselves on Palestine is as revealing of our thinking as our positions on the commodification of social services or the destruction of the planet. Palestine functions very much as a frontier for imperialism and a testing-ground for its technologies of war. It functions equally, therefore, as a magnet and metaphor for anti-imperial analysis and activism. ${ }^{6}$

Said's portrayals of the intellectual are universal in their outlook but very much shaped by his own positioning as a Palestinian intellectual in physical and metaphysical exile. As such, his description of the 'public role of the intellectual' as being one of perpetual 'outsider, "amateur," and disturber of the status quo' is auto-biographical in many respects. ' Said's amateur intellectual is defined by an'unquenchable interest in the larger picture, in making connections across lines and barriers, in refusing to be tied down to a specialty, in caring for ideas and values despite the restrictions of a profession'. ${ }^{8}$ He contrasts such pursuit of truth with 'the insiders, experts, coteries, professionals' and with conformists who fail to question corporate thinking, and class, racial or gender privilege, who fixate instead on 'what is considered to be proper, professional behaviour - not rocking the boat, not straying outside the accepted paradigms or limits, making yourself marketable and above all presentable, hence uncontroversial and unpolitical and "objective"'.9 Such professionalism is marked by an attitude that views scholarship as a nine-to-five pursuit in atomised spaces of niche research, in which the cult of the expert proliferates and intellectual work puts itself in the service of power. In a Western context Said saw this corruption of the role of the intellectual as bound up in depoliticisation, writing in 1988 that 'among the left the use of the word intellectual has fallen into disrepute and disuse. And what instead has appeared are words like professional and scholar and academic ... I think it's partly because of the refusal of American Left intellectuals to accept their political role.'10

The realm of public international law is heavily professionalised, institutionalised and depoliticised. Whether it is human rights or international criminal justice, world trade rules or foreign investment law, the mainstreams of these fields are populated by professional lawyers, academics and advocates who take pride in being part of projects that they see as progressive - advancing rights, combating impunity, facilitating commerce and enterprise. But when it comes to Israel/Palestine these fields are marked by a fundamentally conservative streak. The need to be seen as balanced and to hold both sides of the (uneven) conflict to account - as the international human rights organisations and UN fact-finding missions reporting on Palestine typically oblige themselves to do - obfuscates the structural dynamics of dispossession, exclusion and domination that have long been at play. It is notable that Said specifically cites the international lawyer, along with the military strategist, as exemplifying the type of professional intellectual who speaks and deals in a language that has become highly specialised but largely detached from the material realities over which it is layered. That specialised language masks the brutality of war and occupation, sanitises state violence and terror, barbarises resistance. There is perhaps something in the balancing and equivalencing tendencies of law and legal structures that feeds in to the attitudes of lawyers and helps explain why legal scholars have been particularly reactionary in their engagement on Palestine. Thus we hear the constant refrain of the empty phraseology of 'both sides', 'balance' and 'proportionality'; the internalising of Israel's self-executing right to self-defence; and the incorporation of the insidious euphemisms of 'collateral damage,', 'surgical strikes', 'moderate physical pressure,' 'knocks on the roof', and so on. 
The vocabulary of coloniser and colonised, on the other hand, is largely absent from the lexicon of professional international law when it comes to Palestine, while so many human rights lawyers (both in practice and the academy) are still unwilling to talk about Israeli apartheid or to engage with the Boycott, Divestment and Sanctions (BDS) movement, ${ }^{11}$ for fear of a perceived loss of objectivity. At a time when Israel is ramping up its internal and external efforts to prohibit boycotts by law, when Western governments are signing agreements with Israel that commit themselves to clamping down on BDS activities, ${ }^{12}$ and when US legislators are seeking to use the Transatlantic Trade and Investment Partnership agreement as a vehicle for that same end in Europe, ${ }^{13}$ challenging this orthodoxy remains essential. Principled action does not come without complication, however. Being an intellectual who pursues a 'vocation for the art of representing... involves both commitment and risk.'14 A stated commitment to Palestinian liberation in much of the Western academy and institutional political life bears risks of professional marginalisation as well as the stigma of being branded anti-semitic - as many who speak critically of Israeli state policy (including Jews and Jewish Israelis) regularly are, despite all available evidence and logic.

\section{The Salaita affair}

Some of the limitations that typify professional intellectual thinking can be seen in the debates over freedom of expression that followed the University of Illinois at UrbanaChampaign's (UIUC) termination of the tenured appointment of a Palestinian-American scholar of Native American studies in 2014. Steven Salaita lost his job, essentially, over the positions he took publicly during Israel's summer war on Gaza that year, primarily through the medium of Twitter. From the beginning of the Israeli bombing campaign in early July, Salaita was relatively prolific in his tweets on the situation as it evolved, covering a range of aspects including: updates on the number of children killed by Israeli forces in Gaza; criticism of US support for Israel; mockery of what he characterised as the Zionist propensity to blame Hamas for everything that is wrong throughout the world; emphasis on the importance of BDS as a tactical response to Israeli aggression; and gratitude for what he saw as growing solidarity with Palestinians from around the globe. Some of his posts were marked by a rawness, anger and language that are the product of watching atrocities, injustices and misrepresentations unfold in real time: 'Fuck you, \#Israel. And while I'm at it, fuck you, too, PA, Sisi, Arab monarchs, Obama, UK, EU, Canada, US Senate, corporate media, and ISIS.' ${ }^{15}$

It was because of such utterances that Salaita's contract was revoked, on grounds of 'incivility'. Significantly many of his tweets had engaged the very themes of civilisation and civility, in the context of race and colonialism:

I hope \#lsrael's brutality in \#Gaza compels people to think about the violence inherent to Western notions (and practices) of modernity. ${ }^{16}$

\#Israel has often tested weapons in \#Gaza. That's what most colonizers do to entrapped native populations. They like to call it 'progress. ${ }^{17}$

\#Israel's bombardment of \#Gaza provides a necessary impetus to reflect on the genocides that accompanied the formation of the United States. ${ }^{18}$

The technology of colonialism changes, but in every era the colonizer's great advantage was restricting the geography of the native. \#Gaza. ${ }^{19}$ 
It is worth noting that such conceptually grounded statements outweigh the more visceral formulations in Salaita's Twitter feed that were presented in complaints to UIUC as 'vile', 'vulgar', or 'anti-semitic', and as evidence that Salaita would be better placed in a'loony bin.'20 Salaita explains that he uses Twitter to'put forward a decolonial perspective that draws from certain influences, among them Indigenous thought, critical theory, and literary analysis. Most of my tweets distill decolonial theory into workaday language.'21 This, like Salaita's expressions of gratitude for 'our Jewish brothers and sisters around the world deploring \#lsrael's brutality in \#Gaza,'22 is not acknowledged in the reactionary complaints over his less 'civil' critiques of that brutality. The broader point, however, is that characterisations of the incivility of a racialised voice in a settler-colonial state cannot be viewed in isolation from the historical and ongoing contexts of the 'civilising mission'. The legitimacy of despotic rule over the 'uncivilised' barbarians, and the denial of liberties to them - for their own improvement - is of course central to classic Millsian liberal imperial thought. ${ }^{23}$ Civility is bound up with exclusionary processes designed to construct barriers and keep the ruling classes in the ascendancy. John Locke's political subjects, for example, are defined by their Christianity, their respect for English law and property, and the 'civility in their language..24 This serves a very particular function in colonial projects, with civility of discourse and comport used as a marker of the level (or absence) of humanity and sovereignty in the colonised, and thus implicated in their conquest and extermination.

In a settler-colonial society such as the USA, then, civility does not exist in a historical or ideological vacuum and does not operate as a neutral concept. It is a term with particular imperial and violent sensibilities; it is 'the discourse of educated racism...the sanctimony of the authoritarian...the pretext of the oppressor.25 It is not insignificant that Salaita's scholarship is concerned with comparative settler-coloniality and that his position in Illinois was in an American Indian and Indigenous Studies department. His experience is symptomatic of a broader marginalisation of decolonial pedagogy in US higher education, which extends from Native American to Palestine studies. In the use of the idiom of civility by university administrators engaged in such marginalisation, the echoes of coloniality are stark. In response, Salaita is unapologetic:

Insofar as 'civil' is profoundly racialized and has a long history of demanding conformity to the ethos of imperialism and colonization, I frequently choose incivility as a form of communication. (Or it is chosen for me.) This choice is both moral and rhetorical. Anybody familiar with age-old colonial discourses about the suitability of natives for self-governance understands that the language of civilization is profoundly compromised. Those who decry my 'incivility', then, implicate the cultures and histories from which my rhetoric and morality emerge. ${ }^{26}$

The very purpose of progressive politics is to disrupt accepted orders of power, and to reconstitute what is civil and desirable in society. This is what Palestine solidarity politics does. Conscious of this, invocations of 'incivility' are central to the work of pro-Israel groups in combatting Palestine solidarity organising. Support for Palestinian liberation is invariably dismissed as uncivil, regardless of how respectfully it is articulated. In the face of remorseless state violence against a besieged population, it would appear that Salaita (understandably) prioritises moral clarity over meek platitudes of civility, and language that cuts through the imposed constraints of balance to unmask the gravity of atrocity: 'After all, there is nothing civil about dead children in an ice cream freezer. ${ }^{27}$ Through his 'incivility manifesto', Salaita embraces the charge of incivility as the amateur intellectual's modus operandi - that of 
opposition to militarism and institutional discrimination, antagonism towards the commercialisation of the academy and agitation to democratise academic spaces.

For Joan Scott, who served as chair of the American Association of University Professors' Committee on Academic Freedom and Tenure from 1999 to 2005, civility is now'a synonym for orthodoxy', a framing for the contempt for unorthodox ideas or behaviour which - with its distinctly European Christian bourgeois heritage - 'has become a watch word for academic administrators.'28 Thus it was that Phyllis Wise, the Chancellor of UIUC who oversaw Salaita's dismissal, justified the decision on grounds that tenure 'brings with it a heavy responsibility to continue the traditions of scholarship and civility upon which our university is built..29 The utility of civility as a silencing mechanism is clear, and in this sense it functions in a similar manner to the charge of anti-semitism when it is spuriously invoked to muffle criticism of Israeli state practice. ${ }^{30}$ We can also discern here the type of 'background repression' that preconditions societal norms and mindsets, vitiates objectivity and renders critical voices unacceptable, even where there are no formal restrictions on academic freedom. ${ }^{31}$ Judith Butler explains that the conservative seizure of academic freedom in the USA has emphasised an orthodoxy of 'balance' - with the consequence that state legislatures are empowered to enforce this balance, necessitating surveillance and interference. Academic freedom as such is 'restrictively liberal'; 'if the conservative seizure of academic freedom is to fail, there must be more robust and substantive ways to relate academic freedom to ideals of democracy that include not only right of free expression but opposition to forms of surveillance that target political viewpoints.'32

In this context it seems clear that there are particular political viewpoints that are targeted. UIUC itself provides a number of recent examples that highlight the selectivity of Salaita's punishment: 'Tellingly, in 2012, UIUC took no action when a professor made racist comments at a gathering of white supremacists, and in 2010, UIUC reinstated a lecturer who had been terminated for making homophobic comments in an email to a student.33 And just six months before she presided over Salaita's sacking for his tweets, Chancellor Wise had herself been subjected to a torrent of misogynistic and racist invective by students using a '\#FuckPhyliss' hashtag on Twitter, after she decided not to cancel classes during extreme weather. Despite the vitriolic nature of the tweets, Wise refused to discipline the students, stating: 'The negative comments, as offensive as they were, are protected speech.' ${ }^{34}$ This appears as the tolerance of an authority fully convinced by the sanctity and robustness of its own liberalism, in much the same way that decisions permitting neo-Nazis to parade through a predominantly Jewish suburb (home to many Holocaust survivors), ${ }^{35}$ or allowing homophobes to picket military funerals, are held up as evidence of the unshakeable American commitment to free speech. ${ }^{36}$ These liberal values come undone, however, when it comes to criticism of Israel, such that the Center for Constitutional Rights now speaks of the'Palestine exception' to free speech in the USA. ${ }^{37}$

As such, the Salaita affair raises important questions of political speech, freedom of expression and modes of engagement for public intellectuals, for whom media such as Twitter have become important sites of intervention and intellectual production. The apparently successful interference of private donors with the staff profile of a public university in this case is a chilling turn. While the Committee on Academic Freedom and Tenure that reviewed the case - in response to a complaint by the Department of American Indian Studies against the decision of the University's Chancellor and Board of Trustees - found that the supposed 
'incivility' of a candidate's utterances were not acceptable grounds for the termination of her contract, the spectre of professionalism instead surfaces as an alternative justification:

extramural utterances - political speech -'rarely bear upon a faculty member's fitness for office'. The Chancellor elided the distinction between the two. They should be disaggregated. We do not believe that Dr Salaita's political speech renders him unfit for office. Further, we find that civility does not constitute a legitimate criterion for rejecting his appointment...We do believe, however, that the Chancellor has raised a legitimate question of whether his professional fitness adheres to professional standards. ${ }^{38}$

The question then arises as to how such professional standards are defined or interpreted. One of Salaita's own tweets, just days before his firing, was somewhat prescient in this regard: 'In the United States, academic, corporate, or political respectability is available merely by ignoring Israeli ethnic cleansing. \#Gaza.'39 University of Illinois emails relating to the Salaita affair that were released under a court order in August 2015 provide a telling insight into the thinking of university management on this question of what constitutes professional fitness, standards and values:

A related policy might address the question of'controversial' hires - this is murkier, because people's ideas of what is controversial will differ. But a crude rule of thumb is, if you think someone's name is going to end up on the front page of the newspaper as a $\mathrm{U}$ of I employee, you can't make that decision on your own say so. You need to get some higher level review and approval...We welcome the widest possible range of viewpoints and positions, but not all positions. And that [sic] there are some things that are not consistent with our values. ${ }^{40}$

The University, as the state's public university, needs to, in many ways, reflect the values of the state. ${ }^{41}$

This resembles Said's very definition of the professional intellectual - the duty of an academic intellectual is to conform to the official position; in essence, 'at the University of Illinois at Urbana-Champaign, academic freedom is the freedom to pursue the widest possible range of viewpoints and positions, except for those that are not consistent with our values, which must reflect the values of the state. ${ }^{\prime 2}$ The particular invocation of professionalism in this case finds echoes in the firing of Angela Davis from the University of California, Los Angeles. That university's board of regents had ordered the firing of Davis in 1969 on the basis of her Communist Party membership, but a California Superior Court overturned this. Governor Ronald Reagan continued his crusade to fire Davis, and successfully obtained a decision from the board of regents to do so in 1970, which he said was based 'on her unprofessional conduct as shown by speaking around various campuses already troubled by dissension.43 Her conduct was unprofessional and her rhetoric (in speeches made off-campus) was uncivil - 'inflammatory'.44 Davis was resolute in her (amateur intellectualist) tirade against institutionalised racism and sexism: 'When people start saying that we are out to subvert, that we are subversive, we should say Hell yes, we are subversive. Hell yes, and we're going to continue to be subversive until we have subverted this whole damn system of oppression'. ${ }^{\prime 5}$

More than 40 years later, in railing against the dogma of civility, Salaita is conscious of 'how something that sounds so innocuous, even desirable, is in fact repressive. ${ }^{\prime 6}$ In international law, in many ways, it has been ever thus. The language of 'civilisation' was deployed through foundational international legal doctrines and texts to exclude indigenous and Third World peoples from sovereignty, to rationalise the coloniality of the League of Nations mandates, and to retain a superior standing for 'civilised nations' in the United Nations era, through Article 38(1)(c) of the Statute of the International Court of Justice. For much of international law's history, and to this day, the civilised/uncivilised binary has been a central 
narrative feature. We can look at one international lawyer's intervention in the Salaita debate as illustrative of a broader mindset within the discipline. Dov Jacobs is a legal academic, practitioner and self-described 'expert blogger' on issues of international criminal law and human rights. ${ }^{47}$ In July-August of 2014, while the situation in Gaza was raising numerous questions around the laws of armed conflict and the possible jurisdiction of the International Criminal Court, and while fellow international criminal law bloggers were intensively debating the situation, Jacobs stayed silent on his blog. When he did choose to intervene on events relating to Gaza, it was with a piece not on the war itself but on the Salaita affair, challenging the idea that any principles of academic freedom of expression were at stake in Salaita's case. ${ }^{48}$ Viewed through the lens of Palestine as a litmus test of sorts for intellectuals, the politics of this are not insignificant. Jacobs took particular issue with the tweet in which Salaita referred to the Israeli Defence Forces (IDF) spokesperson as a 'lying motherfucker'. A statement like this, Jacobs said, cannot stem from any academic thinking; it is just a crude insult. Jacobs contrasted this to his own approach, whereby he 'always provides detailed reasoning' for any 'strong feelings' he might have on the tribunals, prosecutors or judges in The Hague. If he were to use a profanity to describe the Prosecutor of the International Criminal Court, he would not see it as unjustified for his employers to fire him. ${ }^{49}$

Part of the problem with Jacobs' response is that his discussion of Salaita's tweet as 'generally insulting' and 'simply being very rude' (which itself, as I have noted above, is not fully representative of the larger collection of Salaita's tweets) is based on a de-contextualised and apolitical understanding of the term 'motherfucker'. This is a professional intellectual perception which elides the distinct social and historical trajectories of the word in the USA as it emerged from the slave plantations, was carried on though jazz culture, given a revitalised political content by black power movements in the 1960s and 1970s, and continues to enjoy widespread and often politicised usage in contemporary hip-hop culture. As Michael Kearney points out, Salaita, as a person of colour in the USA, is situated firmly in this tradition of minority dissent and resistance..$^{50}$ And as a postcolonial scholar of Palestinian origin, Salaita is doubtless well-versed in Said's contention that: 'Knowing how to use language well and knowing when to intervene in language are two essential features of intellectual action'. ${ }^{51}$ Salaita could have chosen any number of words to describe the IDF spokesperson, but he chose a term that has a particular identification with opposition to establishment racism or violence and is widely understood in that context: at least for certain communities but 'perhaps not for white academics.'52 As Earl Washington explains:

The white majority culture tends to put what the black minority culture says into its own (white) frame of reference. Consequently, whites would define 'motherfucker' as a very negative and slang term - literally incest. That definition, however, is only one intended by those who use the word. ${ }^{53}$

Calling the Israeli army spokesperson a lying motherfucker should be understood not as a mindless insult, but as a challenge to the political language used to defend the massacre of Palestinians and as an assertion of the falsehood upon which that defence rests. Political language deployed by the state apparatus is, of course, often an exercise in defending the indefensible, 'designed to make lies sound truthful and murder respectable. ${ }^{54}$ This essentially is one of the functions of the military spokesperson when Israeli forces engage in the bombardment of Gaza. The objection of the professional intellectual in this case, however, appears to be based on the perception of personalised insult, rather than on the allegation of institutional dishonesty. The effect of such an objection is to deflect from the underlying issue 
of an atrocity being perpetrated. The appearance of reasonableness and civility becomes more important than truth itself; the concern is with the 'motherfucker', not the 'lying'. It is this aspect of professionalism - deflection rather than reflection - that we must vigorously contest. C. Wright Mills reminds us of the imperative of heeding the intimate relationship between personal morals, intellect and political stand:'If the thinker does not relate himself to the value of truth in political struggle, he cannot responsibly cope with the whole of live experience. ${ }^{55}$ Resistance to official narratives is essential to smashing the stereotypes with which we are swamped. For Said this necessitates 'unmaskings or alternative versions in which to the best of one's ability the intellectual tries to tell the truth'.56

Since the 2014 war on Gaza we have seen powerful usages of the term 'motherfucker' continuing in public discourse in other situations of structural and racial injustice, most notably in the context of racist police violence in the USA. After the announcement of the grand jury decision not to indict the police officer who killed Michael Brown in Ferguson, Missouri, the Atlanta hip-hop artist and social activist Killer Mike made an eloquent and impassioned speech, telling the agents of power that'you motherfuckers got me today, but you motherfuckers will not own tomorrow', and telling his audience that 'it's about poverty, it's about greed, and it's about a war machine...the one thing I want you to know is that it's us against the motherfucking machine. ${ }^{57}$ Similarly, in a globalisation context, Third World resistance to Western-dominated financial institutions is epitomised in Seun Kuti's characterisation of the IMF as 'international motherfuckers'. The critical awareness among oppressed communities of the role of law and institutional structures in their oppression is crucial here if local resistance and global solidarity is to be able to take root and shape alternative horizons - whether for Palestinians, black communities in the USA or subjugated groups elsewhere. The organic intellectuals in the Black Lives Matter movement are very much aware of this; hence the significance of their visit to Palestine in January 2015 and the ongoing deepening of Black-Palestinian solidarity. ${ }^{58}$ This echoes the ethos of previous generations of African American intellectuals, who saw themselves 'become a Palestinian,'59 or the thrust of a Black Panther party that situated itself in 'radical kinship' with the Palestinians. ${ }^{60}$ Freedom remains a constant struggle in Ferguson and Palestine alike, ${ }^{61}$ where communities continue to be confronted with the physical machine of militarised violence. Intellectuals who challenge the security state justifications for such, meanwhile, are susceptible to different forms of silencing in their own fields.

\section{The Schabas affair}

William Schabas was met by such attempts at silencing upon his appointment as chair of the UN Independent Commission of Inquiry on the 2014 Gaza Conflict. Schabas, like Richard Goldstone before him, would not be considered a radical by any means. He is seen, rather, as an international lawyer with 'perfect professional credentials... a distinguished and justly influential scholar in the field, ${ }^{\prime}$ a progressive but mainstream authority on international human rights law and international criminal law. As such, he might have been assumed a relatively uncontroversial choice for a UN post charged with investigation and documentation of international legal questions in Gaza in comparison to a more critical legal scholar like Richard Falk, whose appointment in 2008 as UN Special Rapporteur on human rights in occupied Palestine incensed Israel and its supporters. Despite this, Schabas faced vehement opposition from the outset. Denunciation from Israel's apologists in UN advocacy circles 
(such as Hillel Neuer and Gerald Steinberg) and in legal academia (Alan Dershowitz and Oren Gross) is perhaps par for the course. But some observers may not have expected to find liberal international lawyers - like Phillipe Sands and Robert Howse - collectively pontificating online about Schabas's purported bias, and the need instead for impartiality and 'the highest standards of judicial integrity'.63 These demands that judicial standards be applied, it must be noted, are made in the context of a fact-finding process with no judicial mandate. Some international lawyers went as far as to argue that the specific criteria applied to judges under the Code of Ethics of the International Criminal Court should be applied to Schabas, in a manner that constructs an indefensible lack of impartiality on his part. ${ }^{64}$ Such expectations are far removed from the human and material realities of people living through conflict and occupation, but are indicative of the type of thinking that is coloured by a perennial need for artificial balance and ostensible professionalism.

As a result of pressure on the UN process from a broad church of pro-Israel campaign groups, think-tanks, political actors and professional intellectuals that threatened to derail the Commission of Inquiry's work, Schabas was ultimately left with little choice but to resign. The primary impetus for the campaign against him was based on a public statement he had made previously (but which was recycled and presented out of context) criticising Israeli military practices and suggesting that Prime Minister Netanyahu may have a case to answer, as well as a legal opinion he had provided to the PLO (regarding technical aspects of accession to the Rome Statute of the International Criminal Court). Although his was not a judicial appointment, supposed standards of judicial independence were applied - liberally constructed not as independence and impartiality in conducting the inquiry itself (which Schabas had fully committed himself to exercising), but as retroactive independence of any opinion on any question relating to the region being investigated. It bears noting that such high thresholds have not traditionally been applied even to international judges themselves. Hersch Lauterpacht, who had furnished legal advice to the state of Israel over the years and had helped draft its declaration of independence, sat as a judge in the Israel v. Bulgaria case in the International Court of Justice. Israel's application was ultimately declared inadmissible in that case, but not without Lauterpacht dissenting.

In Schabas' case, however, because he had expressed opinions on Palestine in the past, he was not deemed an appropriate choice to lead an inquiry on Palestine. This is reflective of an emerging pattern when it comes to international institutional appointments on contested terrain such as this, where relevant experience and prior expressions of opinion or interest can count against an applicant or nominee. Regarding the choice of his own successor as UN Special Rapporteur, Falk points out that Makarim Wibisono'was explicitly chosen in 2014 to be Special Rapporteur for Palestine on the perverse rationale that he was more qualified than other candidates because he had no expert knowledge of the subject-matter. ${ }^{\prime 65}$ Professional human rights intellectuals and international criminal lawyers are expected not to care about Greece or Syria in 2016 any more than they cared about Yugolsavia or Somalia in 1993. There is a professional stigma attached to being overly'passionate' about a particular issue or conflict. International legal historians or researchers who identify with a cause are rebuked on the basis that their work 'fails to provide objectivity'.66 Herbert Marcuse warns of the pitfalls of such fetishisation of nominal objectivity: 'in a democracy with totalitarian organization, objectivity may... foster a mental attitude which tends to obliterate the difference between true and false, information and indoctrination, right and wrong'. 
The result is a neutralization of opposites, a neutralization, however, which takes place on the firm grounds of the structural limitation of tolerance and within a preformed mentality. When a magazine prints side by side a negative and a positive report on the $\mathrm{FBI}$, it fulfills honestly the requirements of objectivity: however, the chances are that the positive wins because the image of the institution is deeply engraved in the mind of the people. Or, if a newscaster reports the torture and murder of civil rights workers in the same unemotional tone he uses to describe the stockmarket or the weather, or with the same great emotion with which he says his commercials, then such objectivity is spurious - more, it offends against humanity and truth by being calm where one should be enraged, by refraining from accusation where accusation is in the facts themselves. The tolerance expressed in such impartiality serves to minimize or even absolve prevailing intolerance and suppression. ${ }^{67}$

Said himself recounts how he'was accused of being active in the battle for Palestinian rights, and thus disqualified for any sober or respectable platform at all'. In contrast to so-called 'universal intellectuals' such as Jean-Paul Sartre or Michel Foucault, those who have been personally involved in any way with a specific cause are cast as biased. For Said, such aspersions amount to'plainly anti-intellectual and antirational arguments' ${ }^{68}$ Hamid Dabashi picks up on this distinction: 'Sartre and Foucault cared widely about the entirety of the colonial and colonizing world, while Fanon and Said cared deeply about Algeria and Palestine, and from these two sites of contestation they extrapolated their politics and ethics of responsibility towards the rest of the world'.69 While Fanon's commitment to Algeria was on the basis of a broader anti-colonial sensibility rather than national identity, and while Sartre and Foucault certainly did not refrain from taking positions on specific sites of contestation, there is something to the suggestion that the European intellectual's engagement is often seen in the West as less 'emotive' than that of the Third World intellectual. The subtext of racialisation is difficult to escape. Indigenous and minority communities in settler-colonial societies are similarly often cast as irrational, to the point that their language may be criminalised on the basis of state claims of violence, whether in the context of anti-segregation activism during the Jim Crow era or hip-hop lyricism today. ${ }^{70}$ For Palestinians, African-Americans and other racialised voices to be seen as professional, they need to appear as devoid of race politics as possible. Such distortions of the 'all lives matter' variety must be exposed and discredited.

International institutional life is not simply a world of insiders and professionals but one of conformists. While there clearly are questions of race at play, when it comes to Palestine it is not only a question of race. Even insiders like Schabas and Goldstone, if they make the mistake of straying beyond the circle or opting not to conform by engaging in 'politicised' processes, will be cast out for behaving in 'unwise and counterproductive' manners that compromise hegemonic conceptions of justice. ${ }^{71}$ Such deviations are framed as individual aberrations (and, for those of Jewish origin, as evidence of 'self-hating' character flaws) and as such are qualitatively different from the constructed cultural deficiencies that exclude Palestinians en masse from the ambit of professional credibility. Both forms must be challenged robustly, however. Said is again instructive here, underlining the importance of the intellectual's role in the 'sense of being unwilling to accept easy formulas, or ready-made cliches, or the smooth, ever-so-accommodating confirmations of what the powerful or conventional have to say, and what they do. Not just passively unwillingly [sic], but actively willing to say so in public. ${ }^{12}$ 


\section{Partisanship and the guerrilla intellectual}

For all of the value that Said's thinking on the representations and affiliations of the intellectual brings in unpacking the dynamics of institutionalised power and opening up spaces of dissent and disruption, his amateur intellectual nonetheless appears at times a somewhat idealised and elite figure. This section thus seeks to home in on a particular sense of partisanship or militancy, so as to distinguish from the kind of liberal advocates who may have similarly romantic ideas of themselves speaking on behalf of the disadvantaged as those which Said ascribes to his truth-seeking intellectual. It also seeks to stretch Said's sometimes narrow conceptualisation of the intellectual as the university intellectual, and to extend his analysis to non-campus spaces.

An academy-centric theory of the intellectual risks side-lining the knowledge production of movement activists and the representative function of working class organic intellectuals, as well as obscuring portraits of the artist as intellectual. Against Said's privileging of the writer-intellectual over the artist-intellectual (painters, film-makers, photographers, hip-hop lyricists, folk troubadours) or the social movement intellectual (political leaders, union activists, grassroots campaigners), Sean Scalmer argues that a 'contemporary sociology of intellectuals needs to encompass diversity. ${ }^{73}$ This is essential to reflect the reality that so many of those who'represent' as socio-political thinkers diverge in expectation, context and priorities from the carefully sculpted image of the book-writing intellectual. This is significant in the context of our discussion of hip-hop above, for instance. How might Said have related to the street culture representations of Black Lives Matter? On one hand, as Scalmer notes, Said's narrow depiction of the intellectual to the exclusion of musical artists, in particular, is surprising given his'musicological passions'. On the other hand, his own aesthetic sensibilities may have meant that the protest missions of hip-hop or folk music were 'not to Said's forbiddingly classical tastes. ${ }^{74}$ This sense of a certain aloofness or elitism also speaks to Said's lack of emphasis on 'activist wisdom' ('practically oriented and contextually bound... painfully acquired and artfully deployed') in his vision of intellectual achievement. ${ }^{75}$

To build on and bolster Said's idea of the virtuous amateur intellectual, then, we can inject it with a more active sense of partisanship and draw on Walter Rodney's notion of the 'guerrilla intellectual'. During his time at the Institute of the Black World in the USA in 1974, Rodney spoke of the 'intellectual struggle' within (and against) an institutional architecture that represents the power of the ruling class.

I use the term 'guerrilla intellectual' to come to grips with the initial imbalance of power in the context of academic learning...the books, the references, the theoretical assumptions, and the entire ideological underpinnings of what we have to learn in every single discipline. Once you understand the power that all this represents, then you have to recognize that your struggle must be based on an honest awareness of the initial disparity. And that's how the guerrilla operates. The guerrilla starts out by saying, the enemy has all and we have nothing in terms of weapons, but we have a lot of other things. ${ }^{76}$

It is in response to such pre-existing imbalances of power that Marcuse calls for pursuit of 'a partisan goal, a subversive liberating notice and practice' as a counterpoint to the entrenched aversion to partisanship in liberal work. ${ }^{77}$ The imperative is to transcend the limitations of liberal freedoms and tolerance, given that their value is premised on an equality that is typically illusory. Where institutionalised inequality, class structures, socio-political privilege and legalised state violence predominate, the conditions of tolerance are inherently loaded. Critical or dissenting speech is subject to background limitations that precede the 
explicit limitations on speech defined by courts and institutions. The freedom of expression that is formally granted in equal measures to all protagonists - whether they advocate hate or humanity - is a form of 'non-partisan tolerance' that is "'abstract" or "pure" inasmuch as it refrains from taking sides - but in doing so it actually protects the already established machinery of discrimination. ${ }^{78}$ As such, there is no neutral position, even in the 'freest' of existing societies. Struggles for freedom are always partisan - intolerant of the repressive establishment and antagonistic to societal structures in which the game is rigged.

Hence Rodney's articulation of the guerrilla intellectual, whose mission is to sabotage the power disparity. Jean Genet saw his support for and engagement with the Palestinian liberation movement (as well as the Black Panthers) as a similar enactment of 'the intellectual as guerrilla'. Genet was, at the same time, careful to emphasise the distinctly anti-colonial contours and qualifications of his partisanship: 'The day the Palestinians become a nation like any other nation, I'll no longer be a part of it.79 Rodney's argument also speaks clearly to Global North-South dynamics, where his metaphor of guerrilla tactics finds echo in Georges Abi-Saab's reflection of 'operating behind enemy lines' as a Third World jurist in Western-dominated international legal institutions. ${ }^{80}$ Given the inequality of arms in these contexts and beyond, for Rodney the task of the guerrilla is to wage a struggle on her own terms, not by confronting the dominant power directly but by occupying the terrain, entering the institutions and setting free the entire structure..$^{81}$

With this in mind, the 'major and first responsibility of the intellectual is to struggle over ideas...in his own sphere of operation' ${ }^{82}$ For many intellectuals this is the sphere of the academy, and requires transformation of their own academic institutions. The Salaita affair reinforces this imperative. The burdens of professionalism and civility arguably weigh more heavily on the university intellectual because of her position in an institutional context. A broader conceptualisation of the intellectual's role challenges the university intellectual to discard those burdens and get her hands dirtier but, as we have seen at UIUC and beyond, this is dis-incentivised by the very nature of the system in which the university intellectual operates. As such, the first point of engagement for the university intellectual is her own sphere of operation. But Rodney's struggle over ideas also entails engaging beyond the university and transcending the distinctions between different forms of labour. The task of intellectuals and educators is that of 'relating ideas to the movement of the masses', both by 'expropriating bourgeois knowledge' and by cultivating alternative and subversive sites of knowledge production. ${ }^{83}$ Rodney's own life and praxis very much straddled academic, activist and community spaces: 'Walter did not confine his activities to the cloisters and lecture rooms at the university, but shared his knowledge and exchanged ideas with the most despised and rejected elements of Jamaican society - the Rastafari brethren' ${ }^{84}$ In this sense he embodies the role of the institutionally embedded but liminal and oppositional scholar, oriented to the South and struggling against (Northern) hegemonic thought, institutions and learning. Rodney's life and work embodied a richness of intersecting contributions from his multiple standpoints as Marxist and Pan-Africanist, university academic and community educator, social critic and political activist. The synthesis of these various ways of being - as enacted across continents - and Rodney's insights on the dynamics of black and Third World political and social development, are of continued value in thinking about praxis of the South. Rodney's admiration for figures like CLR James and Lenin is based on their capacity for intellectualising and doing at the same time; 'for surely there was no real reason why one should remain in the academic world - that is, remain an intellectual - and 
at the same time not be revolutionary'. ${ }^{85}$ This vista of praxis helps us to incorporate some of the practical and tactical aspects of activism into Said's framing of the amateur intellectual.

\section{Amateur international lawyers?}

International law is a space of elite institutions but also a space of social movements. One of the significant contributions of TWAIL scholarship has been to show the possibilities (and importance) of reshaping the field of international law from outside or below, and of imagining counter-hegemonic international law at least coexisting with and destabilising imperial international law, ${ }^{86}$ even if unable to supplant it in the present conjuncture. International legal advocacy from and for Palestine has traditionally deployed quite orthodox legal arguments grounded primarily in international humanitarian law. It has tended for the most part to focus on the need for better institutional enforcement of international law, rather than highlighting law's role in structural oppression. In recent years, however, Palestinian grassroots activism and international solidarity campaigns have begun to use international law, through the BDS movement and other initiatives, in more expansive ways than professional international lawyers and institutions themselves are comfortable with. The task as I see it for anti-colonial or Third Worldist international lawyers (as amateur intellectuals) in thinking about a type of TWAIL praxis in this context is to support and serve such movements where possible and appropriate (with technical contributions), as well as to go beyond the language of law and to continue exposing the biases and blindnesses of the profession (with conceptual contributions and critiques) where necessary.

One crucial role of the intellectual, Said argues, is to dismantle the restrictions that we artificially construct and impose on our thinking and communication. He notes, by way of example, that 'the international lawyer speaks and deals in a language that has become specialized and usable by other members of the same field, specialized experts addressing other specialized experts in a lingua franca largely unintelligible to unspecialized people., ${ }^{87}$ As I have emphasised above, this specialised language that international lawyers speak often serves to obscure the violence of war and occupation and the asymmetries of power relations, or to mask the usurping of popular sovereignty by corporatist ideology. Demystifying the impenetrable language of international trade and investment treaties; problematising the reductive assumptions and classifications of international humanitarian law; challenging and transcending the prevailing orthodoxies in the discourse and landscape of international law; deploying legal language, arguments or tactics with a distinct anti-colonial bent: these can be the contributions of the international lawyer-as-intellectual that offer potential antidotes to outright disenchantment with the law.

Attempts to pursue such antidotes in the Palestinian context may be roughly grouped into three categories. I present these as illustrative of some of the tactics being employed, and do not intend to suggest that what follows is an exhaustive exegesis of the work being done. First, legal processes relating to Palestine can be subverted by activists invoking the prevention of war crimes as their defence against charges of interfering with the property of weapons manufacturers or settlement produce retailers, ${ }^{88}$ by legal representation of the boycott campaigns of unions, associations and solidarity movements who are targeted by Zionism's own reactionary lawfare, ${ }^{89}$ or by the utilisation of quintessentially liberal legal institutions to articulate more radical anti-colonial arguments. Much of this work is essentially 
about 'being political lawyers and using the appropriate doctrinal hooks as they become available'. ${ }^{90}$ Here, advocates for justice for Palestine can take further insights from the work of Jacques Vergès, Third Worldist and internationalist legal practitioner, whose rupture defences went some way to exposing and exploiting the contradictions inbuilt in the French colonial state's use of criminal law against Algerian liberation fighters. Notably it has been said of Vergès that in the professional sense, 'his tactics are anything but lawyerly, but they've succeeded again and again [and] undoubtedly wreak havoc on hyprocrisy'. ${ }^{91}$

Both Steven Salaita's case and the 'Southampton affair' (regarding the cancellation of an international law conference on Israel by University of Southampton management in April 2015 on dubious 'security' grounds) ended up engaging professional sites of law in the form of domestic courts, with somewhat diverging implications for the notion of academic freedom. In August 2015 a United States District Court in Illinois held that Salaita did have a valid case to be answered for breach of contract and violation of his constitutional free speech rights. In November 2015 UIUC settled with Salaita to avoid proceeding to trial, and agreed to pay him damages to the tune of 10 years of his contracted salary. While this amounted to a formal acknowledgment that Salaita had been wronged, he was not reinstated. The 'decimation of the American Indian Studies Program at UIUC [as] an additional price tag paid by the university's capitulation to internal and external forces' is the lingering legacy. ${ }^{92}$ The litigation had secondary impacts in the form of the resignation of Phyllis Wise as UIUC Chancellor (albeit with the cushion of a $\$ 400,000$ severance payment and a $\$ 300,000$ faculty position) and the court-ordered release of university correspondence that exposed management practice. Overall it may be seen as at least a partially successful outcome in terms of protecting free expression rights on Palestine, and as illustrative of the benefits of engaging professional legal institutions in certain circumstances. The English High Court's endorsement of the cancellation of the Southampton conference, by contrast, demonstrates the limitations involved in accessing such conservative spaces.

Second is the move of opening up what we might call alternative 'amateur' arenas of political-legal struggle beyond the courts and the professional institutions. Civil society-led 'people's tribunals' have come to occupy an important space in international affairs in filling certain vacuums left by formal international legal institutions and providing what Falk calls a 'jurisprudence of conscience. ${ }^{93}$ The Russell Tribunal on Palestine can be understood as a kind of amateur international law process which confronts questions that the professional legal institutions in Geneva and The Hague shirk - the arms trade with Israel, European Union complicity in Palestinian suffering, Israel's citizenship, nationality and residency laws as constitutive of apartheid, and corporate profiteering in conjunction with military occupation. The Russell Tribunal has displayed a reach beyond its own proceedings and findings, its multifaceted identity seeing, for example, one jury member (Michael Mansfield) advocating before a UN committee in Geneva one week, another (Roger Waters) discussing Palestinian rights in Rolling Stone magazine the next. Notably, following the findings of the 2011 Russell Tribunal Cape Town session on the apartheid nature of Israeli legal systems and concerted research and activism on the issue by Palestinian social movements and international lawyers, in 2012 the UN Committee on the Elimination of Racial Discrimination was pushed along the unprecedented path of censuring Israel under the rubric of apartheid and segregation. ${ }^{94}$ This evokes the idea of international legal jurisprudence emanating from below. The special session of the Russell Tribunal convened in the wake of Israel's 2014 assault on Gaza was notable for the urgency and efficiency with which it was convened, while so many 
international institutions dallied, and for going beyond the standard war crimes analysis to tackle difficult questions around the proliferation of racist discourse and incitement to violence in Israeli public and political life. ${ }^{95}$ The Hessel Tribunal, a localised version of the Russell Tribunal (named after French second-world war partisan and patron of the Russell Tribunal on Palestine, Stéphane Hessel) hosted by the grassroots Bil'in Popular Committee against the Wall and Settlements in 2013, is another striking demonstration of social movement usage of international law.

While aimed at fundamentally reshaping international law from below, TWAIL scholarship has, however, also shown how this transformative project has been unsuccessful for the most part. The mimicking of classic courtroom structures in these popular tribunal interventions is certainly not without its limitations but at least does hold some value in exposing the structural imbalances in the coloniser/colonised relationship. While it may not be immediately and quantifiably 'effective' in the professional legal sense of delivering a binding and enforceable judgment, the very idea of this type of guerrilla tactic matters - as a disruption of official processes and narratives, as an intervention in the ongoing ideational 'legitimacy war' playing out over Palestine/Israel, ${ }^{96}$ and as a bridge to activism happening outside of legal spaces.

Third, and most importantly perhaps, it is vital for international lawyers to feed into broader political mobilisation and solidarity movements, and for legal actions and BDS activism to complement and reinforce one another. International lawyers are well-placed to support the important work of Palestinian social movements and global solidarity campaigns through, for instance, continued research and analysis of the apartheid features of Israel's population control regime, on the legal intricacies and impacts of settlement colonies, on the nefarious role played by corporate actors that aid and abet Israeli policy, and on any other forms of legal intervention that feed into concrete substantiations of BDS. While the demands of the Palestinian BDS call stem from the language and normative claims of international law, and cannot completely avoid the baggage that this entails, BDS nonetheless provides a blueprint for using international law without being overly hamstrung by the law's internal contradictions and biases.

It is worth contrasting the BDS campaign, as an amateur or organic intellectual movement for Palestinian liberation, with the professional articulation of the PLO's quest for statehood and UN membership. Whereas the statehood initiative collapses the larger Palestinian self-determination claim into one limited element, and has at times reduced the liberation struggle into a question of who to lobby on the Security Council, BDS has provided a mode of praxis for people around the world to respond - in many different and expansive and creative ways - to the call to express material solidarity with Palestine. This is slowly but very surely bearing fruit, ${ }^{97}$ and in this sense the amateur grassroots tactic is proving more successful than the elite professional one. The other key point to emphasise here is that of a given tactic being not only about the concrete result that it achieves in the short term but the platform it lays for the longer-term strategic horizon, and the ways in which organising now shapes the conditions that materialise later. If we think about what the Palestinian liberation project might look like the day after decolonisation, for instance, tactics centred around BDS elicit a vision which avoids simply mirroring failed nationalist state structures that are hierarchical, exclusionary and patriarchal, and imagines instead the possibility of a mode of popular sovereignty that is more open, horizontal and inclusive. 
In a piece on the engagement of international legal scholars with Palestine, Jean d'Aspremont characterises the partisan deployment of international law in pursuit of justice as the intellectual equivalent to hurling stones at an illicit occupying force. ${ }^{98}$ Edward Said of course famously did physically hurl a stone at the edifice of an illicit occupying force. And through this powerfully symbolic act he reminds us of the importance of remaining militant in the pursuit of our political projects, if not in our conviction in the law itself as an end. The challenges before TWAILers and anti-colonial lawyers as amateur or partisan intellectuals, then, involve engaging the law tactically where appropriate, moving beyond the landscape of law where necessary, and exposing the suffocating tendencies of blinkered professional thinking always.

\section{Disclosure statement}

No potential conflict of interest was reported by the author.

\section{Acknowledgments}

Many thanks to the participants in the September 2015 TWAIL/Third World Quarterly writing workshop at the National University of Ireland, Maynooth for their valuable comments on an earlier draft of this article - in particular to Robert Knox and Mazen Masri for their close reading and incisive comments. Thanks also to the anonymous reviewers for their generous and constructive feedback. All errors of style and substance remain mine alone.

\section{Notes on Contributor}

John Reynolds is Lecturer in International Law at the National University of Ireland, Maynooth. His research focuses on the operation of international law in states of emergency and in contexts of conflict, crisis and coloniality. Recent publications include "Anti-colonial Legalities: Paradigms, Tactics \& Strategy" (Palestine Yearbook of International Law, 2015) and "Apartheid, International Law, and the Occupied Palestinian Territory" (European Journal of International Law, 2013).

\section{Notes}

1. Said, Representations of the Intellectual, xvii.

2. Steven Salaita, twitter.com/stevesalaita/status/489022495392301057, July 15, 2014.

3. Cole, "Bad Laws."

4. Said, Representations of the Intellectual, 8.

5. Richard Falk,"A Few Notes on What is Left (orToward a Manifesto for Revolutionary Emancipation)," Global Justice in the 21st Century, https://richardfalk.wordpress.com/2011/06/19/a-few-noteson-what-is-left-or-toward-a-manifesto-for-revolutionary-emancipation, June 19, 2011.

6. Tawil-Souri and Matar, Gaza as Metaphor.

7. Said, Representations of the Intellectual, $x$. See also Said, Out of Place.

8. Said, Representations of the Intellectual, 76.

9. Said, Representations of the Intellectual, xiii, 74 .

10. Said, "American Intellectuals," 44-45.

11. The Palestinian call for boycott, divestment and sanctions (BDS) against Israeli state institutions and agents was issued in 2005 by a broad collective of Palestinian political parties, unions and civil society organisations. It is modelled to a certain extent on the South African 
precedent, and calls for international solidarity in the form of consumer boycotts, commercial divestments and economic sanctions until Israel ends it occupation of Palestinian territory and its systems of racial domination over the Palestinian people. See Palestinian BDS National Committee, "Palestinian Civil Society call for Boycott, Divestment and Sanctions," https://bdsmovement.net/call, July 9, 2005.

12. See, for example, "Memorandum of Understanding between the Department of Foreign Affairs, Trade and Development Canada and the Ministry of Foreign Affairs of the State of Israel regarding Public Diplomacy Cooperation," signed January 18, 2015.

13. “US Trade Bill with EU includes Landmark anti-BDS Provisions," Ha'aretz, June 30, 2015.

14. Said, Representations of the Intellectual, 13.

15. Steven Salaita, https://twitter.com/stevesalaita/status/490871788638072833, July 20, 2014.

16. Steven Salaita, https://twitter.com/stevesalaita/status/495219022607446017, August 1, 2014.

17. Steven Salaita, https://twitter.com/stevesalaita/status/4906972813443397312, July 22, 2014.

18. Steven Salaita, https://twitter.com/stevesalaita/status/490862112957530112, July 20, 2014.

19. Steven Salaita, https://twitter.com/stevesalaita/status/491397701054267393, July 22, 2014.

20. Complaints annexed to: Committee on Academic Freedom and Tenure (CAFT) of the University of Illinois at Urbana-Champaign, "Report on the Investigation into the Matter of Steven Salaita," December 23, 2014.

21. Salaita, Uncivil Rites, 6.

22. Steven Salaita, https://twitter.com/stevesalaita/status/490186075022049280, July 18, 2014.

23. Mill, On Liberty, 24.

24. Locke, Some Thoughts concerning Education, 102.

25. Salaita, Uncivil Rites, 105.

26. Salaita, Uncivil Rites, 42.

27. Salaita, Uncivil Rites, 184.

28. Joan Scott, "The New Thought Police," The Nation, May 4, 2015.

29. Phyllis Wise, "The Principles on which we Stand," https://illinois.edu/blog/view/1109/115906, August 22, 2014 (emphasis added).

30. See, for example, the 'Principles against Intolerance' adopted by the regents of the University of California in March 2016, which conflate anti-Zionism with anti-Semitism, and which Saree Makdisi and Judith Butler describe as 'the latest manifestation of a well-funded and increasingly desperate - even panicky - political campaign to eradicate criticism of Israeli policy from American campuses... a thinly disguised attempt to suppress academic freedom and stifle open debate on our campuses.' Saree Makdisi and Judith Butler, "Suppressing Criticism of Zionism on Campus is Catastrophic Censorship," Los Angeles Times, March 23, 2016.

31. Marcuse, "Repressive Tolerance."

32. Butler, "Israel/Palestine," 16-17.

33. Center for Constitutional Rights, "The Firing of Steven Salaita: Palestine Solidarity and Academic Freedom," http://ccrjustice.635elmp01.blackmesh.com/sites/default/files/attach/2015/02/ Salaita_Factsheet_1-29-15.pdf, January 2015.

34. Phyllis Wise, "Moving past Digital Hate," https://www.insidehighered.com/views/2014/01/30/ chancellor-u-illinois-responds-twitter-incident, January 30, 2014.

35. National Socialist Party of America v. Village of Skokie, 432 US 43 (1977).

36. Snyder v. Phelps, 562 US 443 (2011).

37. Center for Constitutional Rights and Palestine Legal, "The Palestine Exception to Free Speech: A Movement under Attack in the US," http://ccrjustice.org/the-palestine-exception, September 2015.

38. Committee on Academic Freedom and Tenure (CAFT) of the University of Illinois at UrbanaChampaign, "Report on the Investigation into the Matter of Steven Salaita," December 23, 2014.

39. Steven Salaita, https://twitter.com/stevesalaita/status/490672699631742976, July 20, 2014.

40. Email from Nick Burbules (UIUC Professor of Education Policy) to Chancellor Phyllis Wise, February 11, 2014.

41. Email from Christopher Kennedy (Chairman of the UIUC Board of Trustees) to Robert Easter, February 10, 2014. 
42. Corey Robin, "Academic Freedom at UIUC: Freedom to Pursue Viewpoints and Positions that reflect the Values of the State," Crooked Timber, August 10, 2015.

43. Quoted in "Commie Angela Davis is booted from Teaching: Regents finally able to kick Red Afro from Campus, Classes," Desert Sun, June 20, 1970 (emphasis added).

44. Wallace Turner, "California Regents drop Communist from Faculty," New York Times, June 20, 1970.

45. Ibid.

46. Salaita, Uncivil Rites, 60.

47. Jacobs' blog, 'Spreading the Jam', is listed on his CV under the heading 'Expert Blogging'. Said, incidentally, is somewhat scathing of 'expertise and the cult of the certified expert... For "expertise" in the end has rather little, strictly speaking, to do with knowledge.' Said, Representations of the Intellectual, $77,79$.

48. Dov Jacobs, "Is the Salaita Situation really about 'Academic Freedom'?", Spreading the Jam, https://dovjacobs.com/2014/09/13/is-the-salaita-situation-really-about-academic-freedom, September 13, 2014.

49. Ibid.

50. Michael Kearney, Response to Jacobs, "Is the Salaita Situation really about'Academic Freedom'?", Spreading the Jam, September 26, 2014.

51. Said, Representations of the Intellectual, 20.

52. Kearney, Response to Jacobs.

53. Washington, "Black Interpretation," 210.

54. Orwell, "Politics," 265.

55. Wright Mills, The Politics of Truth, 19.

56. Said, Representations of the Intellectual, 22.

57. Alex Young, "Killer Mike gives Emotional Speech in Wake of Ferguson Verdict," Consequence of Sound, November 25, 2014.

58. Kristian Davis Bailey, "Dream Defenders, Black Lives Matter \& Ferguson Reps take Historic Trip to Palestine," Ebony, January 9, 2015.

59. Jordan, Moving towards Home.

60. The influence of the Palestinian struggle on George Jackson's thought and writings in prison, for example, is vividly detailed in an exhibition entitled 'George Jackson in the Sun of Palestine', curated by Greg Thomas of Tufts University and on display indefinitely at the Al-Quds University prisoners' museum in Abu Dis, Jerusalem from October 2015.

61. Davis, Freedom is a Constant Struggle.

62. Joseph Weiler, "After Gaza 2014: Schabas," EJIL: Talk!, November 4, 2014.

63. See https://twitter.com/philippesands/status/562737869719339011.

64. Weiler, "After Gaza 2014."

65. Falk, "Weakening and discrediting the UN: The Mission of Israeli QGOs," Global Justice in the 21st Century, https://richardfalk.wordpress.com/2015/04/17/weakening-and-discrediting-the-unthe-mission-of-israeli-qgos, April 17, 2015. Without sufficient prior knowledge of the region, Wibisono was unprepared for the level of obstruction he would meet from Israel; he resigned as a result after just over a year.

66. Allain, "On Coming to Terms," 155.

67. Marcuse, "Repressive Tolerance" (emphasis added).

68. Said, Representations of the Intellectual, $x$.

69. Dabashi, "The Discreet Charm," 7 .

70. See, for example, Kubrin and Nielson, "Rap on Trial"; and Tanovich, "R v. Campbell."

71. Weiler, "After Gaza 2014."

72. Said, Representations of the Intellectual, 23.

73. Scalmer, "Edward Said," 46, 49.

74. Scalmer, "Edward Said," 45.

75. Scalmer, "Edward Said," 48.

76. Rodney, Walter Rodney Speaks, 111.

77. Marcuse, "Repressive Tolerance." 
78. Ibid.

79. Genet et al., "Jean Genet," 45-46. Genet spent time in Palestinian camps and PLO training bases on the Syrian-Jordanian border in the early 1970s, and was in Beirut at the time of the Sabra and Shatilla massacre in September 1982. See Genet, "Quatre heures à Chatila."

80. Abi-Saab, "The Third World Intellectual in Praxis."

81. Rodney, Walter Rodney Speaks, 112.

82. Rodney, Walter Rodney Speaks, 113.

83. Rodney, Walter Rodney Speaks, 110, 113.

84. "Walter Rodney Memorial Programme," Kensington Town Hall, July 25, 1980.

85. Rodney, Walter Rodney Speaks, 16, 19.

86. Rajagopal, International Law from Below; and Rajagopal, "Counter-hegemonic International Law."

87. Said, Representations of the Intellectual, 9.

88. Richardson v. Director of Public Prosecutions [2014] UKSC 8.

89. R. Fraser v. University \& College Union, 2203390/2011, Judgment of March 22, 2013.

90. Reynolds, "Anti-colonial Legalities," 38. See also Knox, "Strategy and Tactics."

91. Sash Lewis, "The Luminous Bastard," http://sashlewis.blogspot.com/2009/07/luminous-bastard. html, July 10, 2009.

92. "Statement: Over 80 Academics respond to Steven Salaita Lawsuit Settlement," http:// mondoweiss.net/2015/11/academics-settlement-university.

93. Richard Falk, "A Jurisprudence of Conscience," Al-Jazeera, November 23, 2011.

94. Committee on the Elimination of Racial Discrimination, "Concluding Observations: Israel," UN Doc. CERD/C/ISR/CO/14-16, March 9, 2012, para 24. See also Dugard and Reynolds, "Apartheid."

95. The Russell Tribunal on Palestine, "Extraordinary Session on Gaza: Summary of Findings," Brussels, September 25, 2014.

96. Richard Falk, “The Palestinian 'Legitimacy War,'”Al-Jazeera, December 24, 2010.

97. On the successes of the BDS movement, see, for example, Ben White, "Game Changer: 10 Years of BDS," Al-Jazeera, July 9, 2015; and "BDS Victories," https://bdsmovement.net/victories.

98. d'Aspremont, "The International Legal Scholar."

\section{Bibliography}

Abi-Saab, Georges. "The Third World Intellectual in Praxis: Confrontation, Participation or Operation behind Enemy Lines?." Third World Quarterly 2016. doi:10.1080/01436597.2016.1212653

Allain, Jean. "On Coming to Terms with the Israeli Palestinian Conflict: From Coexistence to Conquest International Law and the Origins of the Arab-Israeli Conflict, 1891-1949, Victor Kattan." Book review. Journal of the History of International Law 12 (2010): 155-160.

Butler, Judith. "Israel/Palestine and the Paradoxes of Academic Freedom." Radical Philosophy 135 (2006): 8-17.

Cole, Teju. "Bad Laws." In Letters to Palestine: Writers Respond to War and Occupation, edited by Vijay Prashad, 19-24. London: Verso, 2014.

Dabashi, Hamid. "The Discreet Charm of European Intellectuals." International Journal of Zizek Studies 3, no. 4 (2009): 1-8.

d'Aspremont, Jean. "The International Legal Scholar in Palestine: Hurling Stones under the Guise of Legal Forms?." Melbourne Journal of International Law 14 (2013): 1-17.

Davis, Angela Y. Freedom is a Constant Struggle: Ferguson, Palestine, and the Foundations of a Movement. Chicago, IL: Haymarket, 2016.

Dugard, John, and John Reynolds. "Apartheid, International Law, and the Occupied Palestinian Territory." European Journal of International Law 24 (2013): 867-913.

Genet, Jean, Ruediger Wischenbart, and Gitta Honegger. "Jean Genet: The Intellectual as Guerrilla." Performing Arts Journal 9 (1985): 38-46.

Genet, Jean. "Quatre heures à Chatila." La Revue d'études Palestiniennes 6 (1983): 3-19.

Jordan, June. Moving towards Home. London: Virago, 1989.

Knox, Robert. "Strategy and Tactics." Finnish Yearbook of International Law 21 (2010): 193-229.

Kubrin, Charis E., and Erik Nielson. “Rap on Trial." Race \& Justice 4, no. 3 (2014): 185-211. 
Marcuse, Herbert. "Repressive Tolerance." In A Critique of Pure Reason, edited by Herbert Marcuse, Barrington Moore Jr. and Robert Paul Wolff, 95-137. Boston, MA: Beacon Press, 1969.

Locke, John. Some Thoughts concerning Education, 1693. Reprint, Cambridge: Cambridge University Press, 1934.

Mill, John Stuart. On Liberty. Boston, MA:Ticknor \& Fields, 1863.

Orwell, George. “Politics and the English Language." Horizon 13, no. 76 (1946): 252-265.

Rajagopal, Balakrishnan. International Law from Below: Development, Social Movements and Third World Resistance. Cambridge: Cambridge University Press, 2003.

Rajagopal, Balakrishnan. "Counter-hegemonic International Law: Rethinking Human Rights and Development as a Third World Strategy." Third World Quarterly 27, no. 5 (2006): 767-783.

Reynolds, John. "Anti-colonial Legalities: Paradigms, Tactics \& Strategy." Palestine Yearbook of International Law 18 (2015): 8-52.

Rodney, Walter. Walter Rodney Speaks: The Making of an African Intellectual. Trenton, NJ: Africa World Press, 1990.

Said, Edward W. "American Intellectuals and Middle East Politics." Social Text, no. 19-20 (1988): 37-53.

Said, Edward W. Out of Place: A Memoir. New York: Alfred A. Knopf, 1999.

Said, Edward W. Representations of the Intellectual: The 1993 Reith Lectures. New York: Vintage, 1996.

Salaita, Steven. Uncivil Rites: Palestine and the Limits of Academic Freedom. Chicago, IL: Haymarket, 2015.

Scalmer, Sean. "Edward Said and the Sociology of Intellectuals." In Edward Said: The Legacy of a Public Intellectual, edited by Ned Curthoys and Ganguly Debjani, 36-56. Melbourne: Melbourne University Press, 2007.

Tanovich, David M. "R v. Campbell: Rethinking the Admissibility of Rap Lyrics in Criminal Cases." Criminal Reports (7th) 24 (2016): 27-43.

Tawil-Souri, Helga, and Dina Matar (eds.). Gaza as Metaphor. London: Hurst, 2016.

Washington, Earl M. "Black Interpretation, Black American Literature, and Grey Audiences." Communication Education 30, no. 3 (1981): 209-216.

Wright Mills, C. The Politics of Truth: Selected Writings of C. Wright Mills. Oxford: Oxford University Press, 2008. 